\title{
Proximate composition and antimicrobial activity of three wild edible mushrooms consumed by ethnic inhabitants of Tripura in northeast India
}

\author{
Roy Das $\mathbf{A}^{\mathbf{1}}$, Saha $\mathrm{AK}^{\mathbf{1}}$, and Das $\mathbf{P}^{\mathbf{2}^{*}}$ \\ ${ }^{1}$ Mycology and Plant Pathology Laboratory, Department of Botany, Tripura University, Suryamaninagar-799 022, \\ Tripura, India \\ ${ }^{2}$ Microbiology Laboratory, Department of Botany, Tripura University, Suryamaninagar-799 022, Tripura, India
}

Roy Das A, Saha AK, Das P 2017 - Proximate composition and antimicrobial activity of three wild edible mushrooms consumed by ethnic inhabitants of Tripura in northeast India. Studies in Fungi 2(1), 17-25, Doi 10.5943/sif/2/1/3

\begin{abstract}
The study was focused on edible mushrooms consumed by the ethnic inhabitants of Tripura, northeast India. Three mushrooms namely Lentinus squarrosulus, Lentinus tuberregium and Macrocybe gigantea were evaluated quantitatively for proximate composition and mineral nutrients. In addition, the efficacy of the mycelial extract was tested for antimicrobial activity against the bacteria. The results of this study indicated that mushrooms were rich in protein and carbohydrate with low fat content. Macrocybe gigantea proved to the best source of protein and carbohydrate among the three mushrooms. There were varied amount of micronutrients recorded in all the three mushrooms. The antimicrobial activity of mycelial extract of $M$. gigantea was found against all the tested strains of bacteria. The study suggested that these mushrooms are rich in nutrients particularly $M$. gigantea which could be used as an alternative source of vegetarian food to the ethnic people of Tripura. The antimicrobial activity exhibited by these mushrooms indicated their medicinal properties.
\end{abstract}

Keywords - Antimicrobial activity - edible mushroom - ethnic tribes - macro nutrients - micro nutrients

\section{Introduction}

Mushrooms have gained attention as food, medicine and cosmetics worldwide (Halpern \& Miller 2002, Sliva 2003, Boa 2004, Sliva 2006, Oboh \& Shodehinde 2009, Hyde et al. 2010, Bishop et al. 2015). Mushrooms are considered as source of high protein content, fibre and minerals with low fat content (Leon-Guzman et al. 1997). The consumption of wild edible mushrooms is increasing because of good protein content and trace minerals (Ogundana \& Fagade 1981, Senatore 1990, Thimmel \& Kluthe 1998, Sudheep \& Sridhar, 2014). The macrofungi harbours compounds with broad ranging antimicrobial activity (Barros et al. 2007). A number of compounds isolated from mushrooms possessed antifungal and antibacterial activity (Morita \& Kobayashi 1967, Yasumoto et al. 1971). 
Northeast India is geographically situated in one of the most biodiversity-rich regions of the world (Chatterjee 2008). The diverse climatic conditions prevailing in northeast India harbours a wealth of mushrooms diversity. The consumption of such wild edible mushrooms used by ethnic tribes and local people of northeast from Assam, Meghalaya, Nagaland and Manipur have been reported (Sing \& Sing 1993, Sarma et al. 2010, Tanti et al. 2011, Khaund \& Joshi 2013). Nutritive value of seven wild edible mushrooms commonly consumed by the peoples of Khasi hills of Meghalaya was reported earlier (Agrahar-Murugkar \& Subbulakshmi 2005). The nutraceutical properties of mushrooms consumed by ethnic tribes from this region were studied recently (Khaund \& Joshi 2015). In addition, the nutritional analysis of Pleurotus djamor was also reported from Tripura, northeast India (Roy Das et al. 2014).

The rural tribal people commonly consume wild edible mushrooms growing in the forest beds of Tripura, northeast India. The studies regarding the nutritional evaluation of mushroom from northeast India are scarce. Hence, in the present study we analysed the proximate composition, mineral content and antimicrobial activity of three wild edible mushrooms of Tripura.

\section{Materials \& Methods}

\section{Sample collection}

Three mushrooms were collected from Udaipur Bazar (23 32'03.40"; 91 $28^{\circ} 44.22$ "; 28 masl), Lake Chowmuhani Bazar (23 ${ }^{\circ} 50$ '31.52"; 91 ${ }^{\circ} 16^{\prime} 55.46^{\prime \prime} ; 17$ masl) and homegarden of A.D. Nagar (234' $48.51^{\prime \prime}$; $91^{\circ} 16^{\prime} 20.40^{\prime \prime}$; 24 masl), Tripura in northeast India during AprilOctober, 2015. The collection sites have a humid tropical climate with large amounts of rain. The places experiences long, hot and wet summers, from March to October. Average temperatures is around $32^{\circ} \mathrm{C}$, fluctuating with rainfall. The average humidity ranges between 50 $80 \%$.

\section{Identification of mushrooms}

The collected samples were placed in sterilized plastic bag and brought to the laboratory and accession numbers are MCCT 03, MCCT 04 and MCCT 05, respectively. For identification of the specimens various morphological characteristics were considered and compared (Pegler 1977, Purkayastha \& Chandra 1985, Pegler et al. 1998). The mushrooms were identified by amplifying ITS region of the extracted DNA from the fruit body (Roy Das et al. 2017).

\section{Proximate composition analysis of nutrients}

Moisture, crude fat and crude fibre content were determined following the method of the Association of the Official Analytical Chemist (AOAC 1990). The total protein was analysed (Lowry et al. 1951). Carbohydrate content was estimated (Hedge \& Hofreiter 1962). The ash content was determined (Raghuramulu et al. 2003). Total energy was calculated according to the following equation (Singdevsachan et al. 2015):

$$
\text { Energy }(\mathrm{kcal})=4 \mathrm{x}(\mathrm{g} \text { protein }+\mathrm{g} \text { carbohydrate })+9 \mathrm{x}(\mathrm{g} \text { fat })
$$

\section{Mineral element determination}

For determination of nutrient elements, $0.25 \mathrm{~g}$ of homogenised dried mushroom samples were digested in aqua regia $(15 \mathrm{ml})$ and were incubated at $50^{\circ} \mathrm{C}$ for $30 \mathrm{~min}$, and the temperature was raised to $100-120^{\circ} \mathrm{C}$ for $2 \mathrm{~h}$. After heating, samples were cooled at room temperature, then $10 \mathrm{ml}$ of $0.25 \mathrm{M} \mathrm{HNO}_{3}$ was added, and the mixture was filtered through Whatman paper No. 42. Filtrate was brought to a volume of $25 \mathrm{ml}$ with $0.25 \mathrm{M} \mathrm{HNO}_{3}$ (Radojevic \& Bashkin 1999). Then, elements were quantified by Atomic Absorption Spectroscopy (Perkin-Elmer 3110). 


\section{Determination of antimicrobial activity}

Inoculation of the mushroom mycelium of seven days old cultures was done in $100 \mathrm{ml}$ basal synthetic medium broth (BSM) in $250 \mathrm{ml}$ Erlenmeyer flasks and was incubated for 21 days at $25^{\circ} \mathrm{C}$ in stationary condition. The antimicrobial activity was assessed by disc diffusion method (Bauer et al. 1966). The broth of each submerged mycelium was filtered and the filtrate was used for the antimicrobial activity. The mushroom extract was tested against the bacteria procured from Institute of Microbial Technology (IMTECH) Chandigarh, India. The microorganisms used for investigation were Bacillus subtilis (MTCC-619), Escherichia coli (MTCC-40), Pseudomonas aeruginosa (MTCC-424) and Staphylococcus aureus (MTCC-96). The results obtained was compared with Streptomycin $(100 \mu \mathrm{g} / \mathrm{ml})$.

\section{Data analysis}

The assays were done in triplicates, and the results were expressed as mean $\pm \mathrm{SD}$. The mean values and standard deviation was done using Statistica 9.0. The antimicrobial property was assessed after inoculation with bacteria and zone of inhibition $(\mathrm{mm})$ was noted down after 24-48 $\mathrm{h}$ of incubation. The percentage inhibition was calculated as follows:

$$
\% \text { Inhibition }=\frac{\text { Diameter of inhibition zone }(\mathrm{mm})}{\text { Total diameter of Petri dish }(\mathrm{mm})} \times 100
$$

\section{Results}

\section{Characters of wild mushrooms}

The three mushrooms were collected from markets and one was also from home garden. These are highly priced edible mushrooms which are found in most of the local markets (Fig. 1 a \& c) and were found to be enjoyed by the ethnic inhabitants.

Lentinus squarrosulus Mont.

Synonym: Pleurotus squarrosulus (Mont.) Sing.

Collection site: A.D. Nagar \& Lake Chowmohani

Laboratory accession: MCCT 03 ( 1 b \& d)

Basidiocarps solitary as well as in groups. Pileus: $3-12 \mathrm{~cm}$ diam., depressed at the centre, often deeply infundibuliform, fleshy and pliant when fresh, surface typically white, squamose to squarrose with small concentrically arranged, innate scales which may be concolorous, margin thin, regular or lobed, curved downwards and sometimes involute. Stipe: $2-7 \mathrm{~cm} \times 0.5-2 \mathrm{~cm}$; typically central, attenuated towards the base, cylindrical, firm, solid. Spore print: white.

Lentinus tuber-regium (Fr.) Fr.

Syn. Pleurotus tuberregium (Fr.) Sing.

Collection site: Lake Chowmohani

Laboratory accession: MCCT 04 (1 e)

Basidiocarps solitary. Pileus: $10-17 \mathrm{~cm}$ diam., infundibuliform then expanding although remaining depressed at the centre, flesh becoming coriaceous, surface glabrous, often with small, scattered, isolated appressed squamules particularly towards the centre, creamish white. Stipe 9-12 x 0.8-4 cm, central occasionally excentric, cylindrical, solid surface concolorous with the pileus, generally with isolated appressed squamules similar to the pileal surface. Spore print: white. 

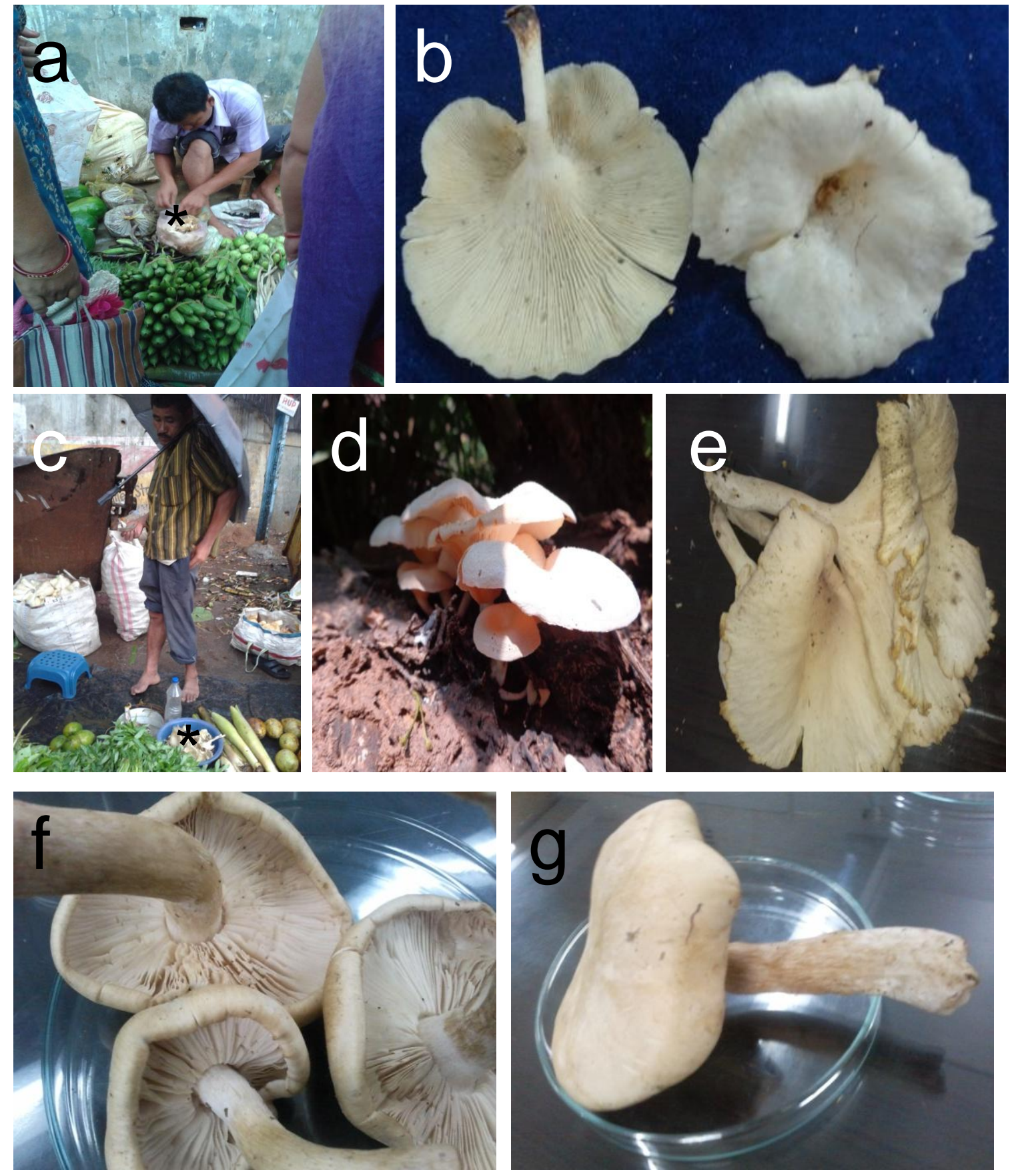

Fig. 1 - The fruit body of mushrooms. a-c The local people selling mushrooms (Lentinus squarrosulus and Lentinus tuber-regium). b-d Fruit body of Lentinus squarrosulus MCCT03. e Lentinus tuber-regium MCCT04. f, g Macrocybe gigantea MCCT05.

Macrocybe gigantea (Massee) Pegler \& Lodge

Syn: Tricholoma giganteum Massee

Collection site: Udaipur

Laboratory accession: MCCT 05 ( $1 \mathrm{f} \& \mathrm{~g})$

Pileus 15-25 cm diam, conicoconvex then expanding; surface greyish green with a glaucous tint, glabrous and silky smooth. Stipe 15-17 x 3-6 cm, cylindrical, often elongate, solid finally fistulose; surface concolorous with pileus, fibrillose-striate, same colour as pileus. Gills white. Spore print white. 


\section{Proximate content of nutrients}

The carbohydrate, protein, fibre and fat content in the mushroom are presented in Table 1. The moisture content of three mushrooms was in the range of $71.13 \%$ and $83.33 \%$. The carbohydrate content obtained in different mushrooms ranged from $48.84 \mathrm{~g} / 100 \mathrm{~g}$ to $52.01 \mathrm{~g} / 100 \mathrm{~g}$. The protein content ranged from $20.97 \mathrm{~g} / 100 \mathrm{~g}$ to $31.04 \mathrm{~g} / 100 \mathrm{~g}$. The fibre content is highest in $M$. gigantea $(10.69 \mathrm{~g} / 100 \mathrm{~g})$ and lowest in L. squarrosulus $(8.32 \mathrm{~g} / 100 \mathrm{~g})$ where as fat content is maximum in L. tuber-regium $(1.77 \mathrm{~g} / 100 \mathrm{~g})$ and minimum in L. squarrosulus $(0.85$ $\mathrm{g} / 100 \mathrm{~g})$. The ash content obtained is higher in L. tuber-regium $(7.73 \mathrm{~g} / 100 \mathrm{~g})$ and lower in $M$. gigantea $(4.53 \mathrm{~g} / 100 \mathrm{~g})$. M. gigantea showed the highest energy contribution $(336.81 \mathrm{kcal} / 100 \mathrm{~g}$ $\mathrm{dw}$ ) and lowest in L. tuber-regium (291.04 kcal/100 g dw). The moisture content is higher in $L$. squarrosulus. The carbohydrate content, fibre content and protein content is higher in $M$. gigantea and L. tuber-regium shows high fat content compared to other two mushrooms (Table 1).

Table 1 Proximate analysis and energy value of three wild edible mushrooms

\begin{tabular}{llll}
\hline Proximate content & Lentinus squarrosulus & Lentinus tuber-regium & Macrocybe gigantea \\
\hline Moisture content $(\%)$ & $83.33 \pm 0.83$ & $76.20 \pm 0.60$ & $71.13 \pm 1.14$ \\
Fibre content $(\mathrm{g} / 100 \mathrm{~g})$ & $8.32 \pm 0.00$ & $9.45 \pm 0.28$ & $10.69 \pm 1.55$ \\
Fat $(\mathrm{g} / 100 \mathrm{~g})$ & $0.85 \pm 0.11$ & $1.77 \pm 0.13$ & $1.27 \pm 0.04$ \\
Carbohydrate content $(\mathrm{g} / 100 \mathrm{~g})$ & $48.84 \pm 0.39$ & $50.03 \pm 0.13$ & $52.01 \pm 0.04$ \\
Protein content $(\mathrm{g} / 100 \mathrm{~g})$ & $27.07 \pm 0.31$ & $20.97 \pm 0.67$ & $31.04 \pm 0.76$ \\
Ash $(\mathrm{g} / 100 \mathrm{~g})$ & $6.32 \pm 0.22$ & $7.73 \pm 0.23$ & $4.53 \pm 0.32$ \\
Energy $(\mathrm{kcal} / 100 \mathrm{~g})$ & $307.19 \pm 2.24$ & $291.04 \pm 6.97$ & $336.81 \pm 3.55$ \\
\hline
\end{tabular}

Mean values $(\mathrm{n}=3)$ with \pm Standard Deviation

\section{Mineral element content}

The mineral nutrients vary in the wild edible mushrooms. L. squarrosulus possesses highest amount of $\mathrm{Ca}, \mathrm{Fe}, \mathrm{Cu}$ and $\mathrm{Mn}$, L. tuber-regium harbours higher amount of $\mathrm{Zn}$ whereas M. gigantea was higher in $\mathrm{Mg}, \mathrm{Cd}$ and $\mathrm{Cr}$ (Table 2).

Table 2 Mineral element analysis ( $\mathrm{mg} / \mathrm{kg}$ ) of three wild edible mushrooms.

\begin{tabular}{llll}
\hline Mineral Elements & Lentinus squarrosulus & Lentinus tuber-regium & Macrocybe gigantea \\
\hline $\mathrm{Fe}$ & $3.6 \pm 0.07$ & $0.49 \pm 0.01$ & $0.27 \pm 0.03$ \\
$\mathrm{Cr}$ & $0.08 \pm 0.005$ & $0.07 \pm 0.001$ & $0.10 \pm 0.008$ \\
$\mathrm{Ni}$ & $0.12 \pm 0.006$ & $0.12 \pm 0.02$ & $0.09 \pm 0.006$ \\
$\mathrm{Zn}$ & $0.23 \pm 0.01$ & $0.24 \pm 0.03$ & $0.15 \pm 0.02$ \\
$\mathrm{Cd}$ & $0.19 \pm 0.02$ & $0.27 \pm 0.008$ & $0.30 \pm 0.01$ \\
$\mathrm{Mn}$ & $0.54 \pm 0.003$ & $0.25 \pm 0.001$ & $0.35 \pm 0.001$ \\
$\mathrm{Cu}$ & $0.89 \pm 0.002$ & $0.44 \pm 0.01$ & $0.55 \pm 0.03$ \\
$\mathrm{Ca}$ & $6.46 \pm 0.12$ & $5.90 \pm 0.04$ & $3.74 \pm 0.16$ \\
$\mathrm{Mg}$ & $7.12 \pm 0.002$ & $9.25 \pm 0.01$ & $21.63 \pm 0.14$ \\
\hline
\end{tabular}

Mean values with \pm Standard Deviation

\section{Antimicrobial activity}

The antimicrobial activity of three wild edible mushroom mycelial extract against Gramnegative bacteria and Gram positive bacteria is depicted in Table 3. Among the three mushrooms, $M$. gigantea showed activity against all the tested bacteria. The zone of inhibition of mycelial extracts of mushrooms against bacteria was comparatively less than the standard antibiotic used. 
Table 3 Inhibition zone of mycelial extract of three wild edible mushrooms

\begin{tabular}{|c|c|c|c|c|c|c|c|c|}
\hline Bacteria & $\begin{array}{l}\text { Lentinus } \\
\text { squarrosulus }\end{array}$ & $\begin{array}{l}\% \\
\text { Inhib } \\
\text { ition }\end{array}$ & $\begin{array}{l}\text { Lentinus } \\
\text { tuber- } \\
\text { regium }\end{array}$ & $\begin{array}{l}\% \\
\text { Inhibi } \\
\text { tion }\end{array}$ & $\begin{array}{l}\text { Macrocybe } \\
\text { gigantea }\end{array}$ & $\begin{array}{l}\text { \% } \\
\text { Inhibit } \\
\text { ion }\end{array}$ & $\begin{array}{l}\text { Strepto } \\
\text { mycin }\end{array}$ & $\begin{array}{l}\% \\
\text { Inhibit } \\
\text { ion }\end{array}$ \\
\hline Bacillus subtilis & $10.23 \pm 0.11$ & 12.79 & $10.35 \pm 0.35$ & 12.94 & $10.55 \pm 0.39$ & 13.19 & $\begin{array}{l}28.26 \pm 0 \\
.40\end{array}$ & 35.33 \\
\hline E. coli & - & - & - & - & $10.21 \pm 0.38$ & 12.76 & $\begin{array}{l}24.85 \pm 0 \\
53\end{array}$ & 31.07 \\
\hline $\begin{array}{l}\text { Pseudomonas } \\
\text { aeruginosa }\end{array}$ & $7.59 \pm 0.23$ & 9.49 & $7.43 \pm 0.46$ & 9.29 & $8.18 \pm 0.57$ & 10.23 & $\begin{array}{l}18.33 \pm 0 \\
.58\end{array}$ & 22.92 \\
\hline $\begin{array}{l}\text { Staphylococcus } \\
\text { aureus }\end{array}$ & $8.10 \pm 0.07$ & 10.13 & - & - & $8.88 \pm 0.30$ & 11.10 & $\begin{array}{l}33.67 \pm 1 \\
.53\end{array}$ & 42.08 \\
\hline
\end{tabular}

Mean values $(\mathrm{n}=3)$ with \pm Standard Deviation

-No activity observed

\section{Discussion}

The variability in moisture content observed in the present study was dependent on the mushroom species and other parameters such as environment, temperature and relative humidity during growth and relative metabolic water that may be produced or utilized during storage (Crisan \& Sands 1978). The protein and carbohydrate content in our study is in accord with the earlier studies (Hung \& Nhi 2012, Chang \& Miles 1989, Khan et al. 2008, Manjunathan \& Kaviyarasan 2011, Rizal et al. 2015).

Out of nine mineral elements detected by AAS analysis, highest amount of four elements were found in L. squarrosulus, three were high in M. gigantea and one was high in L. tuberregium and $\mathrm{Ni}$ was equally found higher in L. squarrosulus and L. tuber-regium. The mineral content of mushrooms was highly variable in the studied mushrooms which is in accord with an earlier report (Khaund \& Joshi 2015).

With an increasing number of bacteria developing resistance to commercial antibiotics, extracts and derivatives from mushrooms hold great promise for novel medicine in modern times (Chikara 1992, Mizuno et al. 1995). In recent decades, various extracts of mushrooms have been of great interest as sources of natural products (Alves et al. 2012a). In the present study, the extracts of three mushrooms inhibited both Gram positive and negative bacteria suggesting broad-spectrum antimicrobial potential, $M$. gigantea exhibiting the most satisfactory results by inhibiting all the four tested bacterial strains. The mushroom species are potentially a rich source of antimicrobial agents (Kalyoncu 2009, Vamanu 2012, Alves et al. 2012b) which is in accord with our study.

Studied species are good sources of nutrients with high carbohydrate and protein content having varying amount of mineral nutrients. The cultivation of these mushrooms in Tripura particularly $M$. gigantea would possibly supply a constant alternative vegetarian food to the locals and ethnic people of Tripura. The antimicrobial activity exhibited by these mushrooms indicated their medicinal properties. The commercial cultivation of these mushrooms could capture the market as popular dietary items of the locals and ethnic people of this region.

\section{Acknowledgements}

The authors are grateful to the Head, Department of Botany, Tripura University for providing the facilities. ARD is thankful to the State Biotech Hub Project, Department of Biotechnology, and Government of India for the fellowship. The authors are grateful to Sophisticated Analysis Instrumentation Facility, NEHU, Shillong for analysis of micronutrients using Atomic Absorption Spectroscopy. 


\section{References}

Agrahar-Murugkar D, Subbulakshmi G. 2005 - Nutritional value of edible wild mushrooms collected from the Khasi hills of Meghalaya. Food Chemistry 89, 599-603.

Alves MJ, Ferreira IC, Dias J, Teixeira V, Martins A, Pintado M. 2012a - A review on antimicrobial activity of mushroom (Basidiomycetes) extracts and isolated compounds. Planta Medica 78(16), 1707-18.

Alves MJ, Ferreira ICFR, Martins A, Pintado M. 2012b - Antimicrobial activity of wild mushroom extracts against clinical isolates resistant to different antibiotics. Journal of Applied Microbiology 113, 466-475.

AOAC. 1990 - Association of Official Analytical Chemist, Official Methods of Analysis. $15^{\text {th }}$ edition Washington DC, 650-681.

Barros L, Calhelha RC, Vaz JA, Ferreira ICFR, Baptista P, Estevinho LM. 2007 Antimicrobial activity and bioactive compounds of Portuguese wild edible mushrooms methanolic extracts. European Food Research Technology 225(2), 151-156.

Bauer AW, Kirby WM, Sherris JC, Turck M. 1966 - Antibiotic susceptibility testing by a standardized single disk method. American Journal of Clinical Pathology 45, 493-496.

Bishop KS, Kao CH, Xu Y, Glucina MP, Paterson RR, Ferguson LR. 2015 - From 2000 years of Ganoderma lucidum to recent developments in nutraceuticals. Phytochemistry 114, 5665.

Boa E. 2004 - Wild edible fungi a global overview of their use and importance to people, Rome (Italy): FAO.

Chang ST, Miles DG. 1989 - The nutritional attributes and medicinal value of edible mushrooms. In Edible mushrooms and their cultivation 27-40, Boca Raton, FL, CRC Press.

Chatterjee S. 2008 - Biodiversity Conservation Issues of Northeast India. International Forestry Review 10(2), 315-324.

Chikara G. 1992 - Immunopharmacology of lentinan, a polysaccharide isolated from Lentinus edodes: Its application as a host defense potentiator. International Journal of Oriental Medicine 17, 55-77.

Crisan EV, Sands A. 1978 - Nutritional value, In: Chang ST, Hayes WA, editors. The biology and cultivation of edible mushrooms, USA, New York Academic Press, 137-165.

Halpern GM, Miller AH. Medicinal mushrooms, 2002 - New York (NY): M Evans.

Hedge JE, Hofreiter BT. 1962 - Carbohydrate Chemistry (RL Whistler and JN Be Miller, eds), Academic Press, New York .

Hung PV, Nhi NNY. 2012 - Nutritional composition and antioxidant capacity of several edible mushrooms grown in the Southern Vietnam. International Food Research Journal 19(2), 611-615.

Hyde KD, Bahkali AH, Moslem MA. 2010 - Fungi - an unusual source for cosmetics. Fungal Diversity 43(1), 1-9.

Kalyoncu F, Oskay M, Sağlam H, Erdoğan TF, Tamer AÜ. 2009 - Antimicrobial and antioxidant activities of mycelia of 10 wild mushroom species. Journal of medicinal food 13(2), 415-419.

Khan MA, Tania M, Amin SMR, Uddin MN. 2008 - An Investigation on the nutritional composition of mushroom (Pleurotus florida) cultivated on different substrates. Bangladesh Journal of Mushroom 2 (2), 17-23.

Khaund P, Joshi SR. 2013 - Wild edible macrofungal species consumed by the Khasi tribe of Meghalaya, India. Indian Journal of Natural Products and Resources 4(2), 197-204. 
Khaund P, Joshi SR. 2015 - Functional nutraceutical profiling of wild edible and medicinal mushrooms consumed by ethnic tribes in India. International Journal of Medicinal Mushrooms 7(2), 187-197.

Leon-Guzman MF, Silva I, Lopez MG. 1997 - Proximate chemical composition, free amino acid contents, and free fatty acids contents of some wild edible mushrooms from Queretaro, Mexico. Journal of Agriculture and Food Chemistry 89, 533-539.

Lowry OH, Rosebrough NJ, Farr AL, Randall RJ. 1951 - Protein measurement with the Folin phenol reagent. Journal of Biological Chemistry 193, 265-275.

Manjunathan J, Kaviyarasan V. 2011 - Nutrient composition in wild and cultivated edible mushroom, Lentinus tuberregium (Fr.) Tamil Nadu, India. International Food Research Journal 18, 809-811.

Morita K, Kobayashi S. 1967 - Isolation structure and synthesis of lenthionine and its analogs. Chemical and Pharmaceutical Bulletin 15, 988-993.

Mizuno T, Saito H, Nishitoba T, Kawagishi H. 1995 - Antitumour- active substances from mushrooms. Food Reviews International 11, 23-61.

Oboh G, Shodehinde SA. 2009 - Distribution of nutrients, polyphenols and antioxidant activities in the pilei and stipes of some commonly consumed edible mushrooms in Nigeria. Bulletin of the Chemical Society of Ethiopia 23(3), 391-398.

Ogundana SK, Fagade O. 1981 - The nutritive value of some Nigerian edible mushrooms. In: Mushroom Science XI, Proceedings of the Eleventh International Scientific Congress on the Cultivation of Edible Fungi, Australia, 123-131.

Pegler DN. 1977 - A Preliminary Agaric Flora of East Africa. Kew Bulletin, Addit Ser VI.

Pegler DN, Jean Lodge D, Nakasone KK. 1998 - The pantropical genus Macrocybe gen. nov. Mycologia 90(3), 494-504.

Purkayastha RP, Chandra A. 1985 - Manual of Indian edible mushrooms. Today and Tomorrow's Printers and Publishers, New Delhi, India.

Radojevic M, Bashkin VN. 1999 - Practical Environmental Analysis. 1st Edn., The Royal Society of Chemistry, UK, ISBN-13: 9780854045945, 466.

Raghuramulu N, Madhavan NK, Kalyanasundaram S. 2003 - A Manual of Laboratory Techniques. pp. 56-58, National Institute of Nutrition. Indian Council of Medical Research, Hyderabad, India.

Rizal LM, Hyde KD, Chukeatirote E, Chamyuang S. 2015 - Proximate analysis and mineral constituents of Macrolepiota dolichaula and soils beneath its fruiting bodies. Mycosphere 6(4), 414-420.

Roy Das A, Das P, Bhattacharjee S, Saha AK. 2014 - Chemical analysis of a wild edible mushroom: Pleurotus djamor (Rumph. ex Fr.) Boedijn. Mushroom Research 23(2), 161166.

Roy Das A, Borthakur M, Saha AK, Joshi SR, Das P. 2017 - Molecular characterization and antioxidant potential of three wild culinary-medicinal mushrooms from Tripura, Northeast India. International Journal of Medicinal Mushrooms, 19(1), 55-63.

Sarma TC, Sarma I, Patir BN. 2010 - Wild edible mushrooms used by some ethnic tribes of Western Assam. Bioscan 3, 613-625.

Senatore F. 1990 - Fatty acids and free amino acid content of some mushrooms. Journal of Science and Food Agriculture 51, 91-96.

Sliva D. 2003 - Ganoderma lucidum (Reishi) in cancer treatment. Integrative Cancer Therapies 2(4), 358-364.

Sliva D. 2006 - Ganoderma lucidum in cancer research. Leukemia Research 30, 767-768.

Sing NI, Sing SM. 1993 - Edible Fleshy Fungal Flora of Manipur. Bioveel 4(2), 153-158.

Singdevsachan SK, Patra JK, Tayung K, Thatoi H. 2015 - Chemical constituents, antioxidative and antibacterial properties of medicinal mushrooms collected from Similipal Biosphere 
Reserve, Odisha, India. Proceedings of the National Academy of Sciences, India, Section B: Biological Sciences DOI 10.1007/s40011-015-0574-1.

Sudheep NM, Sridhar KR. 2014 - Nutritional composition of two wild mushrooms consumed by the tribals of the Western Ghats of India. Mycology 5(2), 64-72.

Tanti B, Gurung L, Sarma GC. 2011 - Wild edible fungal resources used by ethnic tribes of Nagaland, India. Indian Journal of Traditional Knowledge 10, 512-515.

Thimmel R, Kluthe R. 1998 - The nutritional database for edible mushrooms. Ernahrung 22, 63-65.

Vamanu E. 2012 - In vitro antimicrobial and antioxidant activities of ethanolic extract of lyophilized mycelium of Pleurotus ostreatus PQMZ91109. Molecules 17, 3653-3671.

Yasumoto K, Iwami K, Mitsuda H. 1971 - A new sulfur-containing peptide from Lentinus edodes acting as a precursor for lenthionine. Agricultural and Biological Chemistry 35, 2059-2069. 